\title{
Technology, a Stratifying Learning Utility?: A Comparative Case Study of a Rural and an Urban Day Secondary Schools in Masvingo, Zimbabwe
}

\author{
Daniel Madzanire (Mr) \\ Great Zimbabwe University Box 1235, Masvingo, Zimbabwe \\ Email: danielmadzanire@gmail.com \\ Corinne Meier (Prof) \\ Department of Early Childhood Development, Box 392, 0003, Pretoria, UNISA \\ Email:meierc@unisa.ac.za
}

Doi:10.5901/jesr.2014.v4n3p307

\begin{abstract}
The study focused on how technology as a learning utility created a learning gap that stratified learners. Apart from establishing the learning gap that is created by technology in rural and urban day secondary schools, it sought to suggest ways in which learning gaps could be minimised. A comparative case study research design which is largely qualitative was used. It permitted the researchers to describe in detail how technology created a learning gap that stratified rural and urban day secondary school learners. A sample of 48 participants comprising 4 teachers, 4 administrators and 40 learners from a rural and an urban day secondary school was purposively drawn. It emerged from the study that learners who used technology did not only outperform their counterparts but they were better prepared for their future careers. Recommendations were made for the stakeholders to facilitate the use of technology in enhancing learning in rural and urban day secondary schools.
\end{abstract}

Keywords: technology stratifies gap career learner

\section{Introduction}

It is a fact in the world that computers are a reality we are facing today. Informatization is the order of the day. It refers to the "information technologies such as the World Wide Web (www), which have transformed the society" (Sibanda \& Maposa, 2010:15). Apart from being ubiquitous, technology is superseding all societal institutions. Education is one such institution in which the use of a computer as a teaching-learning tool is gaining momentum. The current trend in the world is towards a computerized world (Zhao, 2009). Moving in tandem with the current world trend, the Zimbabwean government launched a national e-learning programme championed by the president. The Minister of Information and Communication Technology (ICT), Mr Nelson Chamisa indicated that the national e-learning programme supplied each secondary school with computers, a projector, a printer and a VSAT (Very Small Aperture Terminal) for internet (Tech Zim, 2012). In a bid to minimise technology-rooted learning gaps, the government avails solar energy to schools situated where there is no electricity. By thrusting upon connectivity, hardware, software and solar power; the government is preparing the students for the demands in the $21^{\text {st }}$ century.

In schools, computers are used as interactive tools that enhance teacher-learner as well as learner-learner interaction (Berns, 2010). This crucial interaction occurs through debates, discussions and feedback that take place at both local and international levels. Interaction with far away peers does not only widen a learner's academic experience but as well prepares him or her for the life world. The use of computers is amongst others a very important way in which

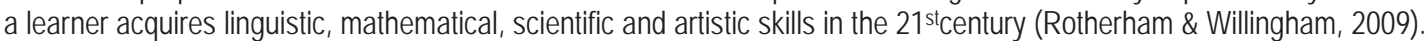
A skills gap is created where urban and rural learners do not use computers. Such a gap may be difficult to cover since the skills that are inculcated in learners today lay the foundation for the future technological demands. In connection, Litz cited in Dlamini (2012:6) asserts that "current skills should enable the learner to answer in twenty years, questions we cannot even begin to ask today". Thus technology creates critical, problem solving learners who can identify and respond to challenges that are yet unforeseen (Dlamini, 2012). Learners, who are left behind, find it difficult to catch with technology which is a reality in schools and society in general.

Convenience that comes with the use of technology cannot be sacrificed. Dlamini (2012) reiterated that computers 
have conveniently replaced paper by soft copies of everything from textbooks to examinations. The trend towards computer-based learning means that learners should be prepared for it as an imminent change. Gone are the days when schools lamented the scarcity of textbooks. What they require is current computer technology. Hudson (2012) observes that computers reduce errors in learning in that calculations and grammatical mistakes can be easily checked. Once the technology gap is closed, learners can easily fit into the world. Discussing the utility of computers in reducing learning gaps cannot be complete without mentioning mobile phones which can be equally handy. Mobile phones can enhance skills just like computers. In fact, mobile phones are cheaper and more convenient than computers (Chinnery, 2006; Kakulski, Hulme \& Traxler, 2005). The potential of mobile phones to reduce technological-rooted learning gaps is discussed further under literature review.

In a bid to bring technology to the door step of every learner in Zimbabwe, the president donated computers to rural and urban secondary schools. Each secondary school rural or urban received at least ten computers (Tech Zim, 2012) which if utilised can effectively reduce learning gaps in rural and urban secondary schools. Research has revealed that the donated computers are underutilised. A preliminary research survey in which the participants were 10 Great Zimbabwe University Bachelor of Arts (BA) Part one students who had attended rural and urban day secondary schools revealed that students lacked basic computer skills because computers that were donated to secondary schools were underutilised. The students who hailed from rural and urban secondary schools could not access internet, let alone type their assignments. This deficiency in using computers slowed down the speed at which the students accomplished their research work especially the first assignment. Thus the technology-rooted learning gaps that are created during secondary level haunt a learner through higher education and beyond.

Prompted by a preliminary survey mentioned above the researchers took a quest to investigate how learners were stratified by the technology-rooted learning gaps in both rural and urban day secondary schools. Rural day secondary schools unlike urban day attract learners from low income background whose parents struggle to raise fees. They lack such necessities as electricity, furniture and qualified personnel which urban day secondary schools enjoy. The aforementioned differences determine the curriculum that is offered. For instance, an urban day secondary school can offer computer examinations while its rural counterpart offers computer lessons as an appreciation course.

\section{Statement of the Problem}

The study undertook to investigate the extent to which technology creates a learning gap that stratifies rural and urban day secondary school learners.

\section{Objectives of the Study}

The study was guided by the following objectives:

- To establish the learning gap that is created by technology in rural and urban day secondary schools.

- To investigate the extent to which technology rooted learning gaps stratify rural and urban day secondary school learners.

- To suggest ways in which the learning gaps can be minimised in urban and rural day secondary schools.

\section{Theoretical Framework}

This study is informed by the instrumentation framework which according to Suther, Robertson and John (2009), was initiated by Verillion and Rabardel (1995) and brought into perspective by Mariotti (2002). The instrumentation framework hinges upon the thinking that specific appropriation of a computer as a tool makes it versatile in that it can be adopted for various uses. In other words, tools that are designed to perform specific tasks can effectively be used to accomplish other tasks for which they were not designed. For example, mobile phones which are basically designed for communication can be used to enhance learning. By appropriation, it is meant "the process of taking something that belongs to others and making it one's own" (Wertsch, 1998:53). In the context of this study, computers and mobile phones can be utilised as sources of information and skill-enhancing devices.

Two aspects of a tool are distinguished, the artefact and the instrument (Mariotti, 2002). The term artefact refers to "the particular object with its intrinsic characteristics, designed and realised for the purpose of accomplishing a particular task" (Mariotti, 2002:702). What it means is that technology is designed to carry out a specific task but the advantage of using a computer or a mobile phone is that it can be appropriated to accomplish a task of choice. A learner can 
appropriate a computer to learn just as a teacher can adopt it for teaching. When it is appropriated for a specific use, a computer becomes a worthwhile instrument (Mariotti, 2002). An instrument is "the artefact and modalities for its use, as elaborated by the particular user in accomplishing different tasks" (Mariotti, 2002:702). If computers and mobile phones are not utilised as instruments, a learning gap is created between learners who use them to learn and those who do not. Learners, who use computers and mobile phones as learning instruments, achieve more in education (Trouche, 2003).

Mariotti (2002) and Trouche (2003) note that a particular artefact can serve as several instruments in different situations. The instrument orchestration process enables learners to develop different instruments and meanings from the same artefact (Suther, Robertson \& John, 2009). Learners, who use technology to learn, gain more knowledge since the instrument orchestration process connects them to vital information which is found on the internet. In light of the instrumentation framework, schools should create a learning environment that permits learners to turn available technology into learning instruments. Technology largely determines the extent to which a learner accesses knowledge (Lyotard in Haralambos, Holborn \& Heald, 2008). Learning gaps that exist among learners can be covered if technology is properly appropriated in schools.

\section{Literature on Technology}

The world in which we are living is not only characterised by technology but it also demands a computer literate workforce (Giddens, 2009). Education as an institution is not an exception since it has as its task to produce computer literate graduates. The advent of computers means that teachers and learners will not do business as usual. In the prolegomena of his book 'Technology in Higher Education' Siddiqui (2004:iii) reports that "the rapid breakthrough in new information and communication technologies (ICTs) is changing the way knowledge is developed, acquired and delivered". As computers find their way into schools, some remain without the desired technology. Watkins (2000) sees the exclusion of learners from this new technology as a danger. Given the fact that many learners do not have access to a computer both at home and at school (Giddens, 2009), the technology-based learning gap is bound to occur in schools. Such threatening gaps should be covered as a matter of urgency if schools are to effectively deliver their mandate.

The learning gaps go beyond the secondary and tertiary levels of education. Watkins (2000) argues that failure to close the information and technology gap which is now opening up between school systems in rich and poor worlds will inevitably result in increasing income inequalities. In the same vein, Giddens (2009:874) reports that "if schools do not provide better access to computing, then the social class divide in education systems looks likely to become wider". Technology is revolutionizing the knowledge realm. Learners who are out of touch with technology can be regarded as the illiterate, the poor, or even the backward. Giddens (2009) notes that a 'computer underclass' that is, a computer illiterate group, is feared to be emerging. In other words, a computer is an emerging force that stratifies. This computer stratification manifests in various institutions of which education is one. As it pervades education, computer stratification creates a learning gap that feeds into other institutions. This research sought to investigate how such learning gaps impeded learning and differentiated learners.

Attainment gap is to some extent technologically-inclined. A survey carried out on primary school teachers 2006 (Kitchen, Finch \& Sinclair, 2007) revealed that three quarters of teachers agreed that ICT could have a positive impact on attainment. Giddens (2009) cites a 2003 Organisation for Economic Co-operation and Development (OECD) study which upon assessment of educational performance of 15-year -olds found that regular computer use led to better scores particularly in Mathematics. These studies confirmed the power of ICT as a determinant of differential attainment in education. Viewed in this light, schools should address technological gaps if learners are to benefit.

The technology-based learning gaps do not close once computers are availed to schools. In the mid 80s, the thinking was that people would automatically take advantage of the opportunities that technology offered once it was made available (Perkins, 1985). This did not work. Technology-rooted learning gaps can remain in schools if computers are not utilised. Turkle and Paperl (1990) observe that adults and young people do not automatically take new technologies on board.

Technology-rooted learning gaps can be prompted by the view of technology education in secondary schools as an elective programme that is, one of the practical subjects (Siddiqui, 2004). With the government e-learning programme not fully operational in Zimbabwe, some rural and urban day secondary schools rely on the 1996 Higher Education Examinations Council (HEXCO) as an examining board for practical subjects like computers, Home Economics and Art. Under the HEXCO syllabus, fragmented computer courses like computer operation packages, electronic data processing concepts, computer organisation and design as well as computer programming are examined (HEXCO, 1996). The view of computers as one of the practical subjects but not as a learning tool is a form of social closure in that learners who do 
not take the computer option become technologically marginalised as they rarely experience computers at school. Thus, a learning gap which is difficult to cover is created as long as students do not use technology to learn.

Learning gaps can be minimised by building computer confidence in learners (Siddiqui, 2004). Students need to gain confidence by interacting with the computers. Computers can present and store information, motivate learners and reward them, provide drill and practice as well as individualised instruction all of which have the capacity to build computer confidence (Openheimer, 2003; Berns, 2010). Such interaction with computers encourages learners to reflect and modify their thinking (Siddiqui, 2004). Lack of computer confidence is not only a learner issue, but also a teacher's challenge. Hargreaves, Comber and Galton (1996) found that teachers indicated their lack of confidence in ICT by rating it highly as a training need. Both teachers and learners should be encouraged to appropriate ICT in order to enhance teaching and learning. When teachers and learners garner confidence in ICT, they use it and therefore close the learning gaps.

Apart from instilling confidence, technology interconnects curricular subjects. Siddiqui (2004) observes that technology adds meaning to various subjects by interconnecting them so that they form a robust body of knowledge. A learner can access knowledge on various subject areas on the computer. Learning gaps fill as technology is used to join fragmented experiences.

In the realm of research, technology offers peculiar opportunities (Smith, 1999). Learners can research on topics with the help of online resources (Giddens, 2009). They can tweet or skype to connect with experts that is, other people who share similar interests as theirs (http://theinnovativeeducator.blogspot.com/2011/01/10-ways-technilogy-supports21st.html). Learners can learn further in their areas of interest with the aid of technology. Learning gaps are closed as experts guide them online. On top of that, learners can access free online resources which consolidate the concepts that they learn. The William and Flora Hewlett Foundation (2012) reports that open online educational resources avail the world's knowledge as a public good to everyone. Learners close learning gaps as they share, use and re-use knowledge without the hand of the teacher.

Apart from online resources, learners who use computers can benefit from educational software (Giddens, 2009; Oppenheimer, 2003). Educational software for Geography, Mathematics and Science or Music can be used for learning regardless of the non- availability of internet. Students can meaningfully interact with the computers even if they are offline. Offline interaction with computers can reduce technology-rooted learning gaps.

Computers and mobile phones can be complementary. Mobile phones especially the modern smart ones cannot be ignored in forum where technology is the subject of discussion. Although mobile phones come with potential risks; numerous benefits accrue from using them as learning tools. A case in point is nuclear power. While it is a reliable source of energy for human consumption, nuclear power can twisted to become a weapon of mass destruction. For instance, the nuclear power which was used to exterminate Japan's Hiroshima and Nagasaki cities during the Second World War is used as a source of energy in countries like Iran and North Korea. The mobile phone is infamous for disrupting learning and important meetings in schools. Notwithstanding that, it can be appropriated to enhance learning. This observation dovetails with Trouche's (2003) report that a particular artefact or tool can serve as several instruments in different situations. In the case of education, the argument is that schools should not watch cell phones distracting learning. Instead, they should appropriate them to enhance learning. If this happens, technological learning gaps can be tremendously reduced.

There are pedagogical benefits of using mobile phones as learning tools. Tremendous research can be done through mobile phones. Mobile phones are small computers with internet capabilities, games, pictures, videos, texting and email (http://www.ehow.com/list_5955529_cell-phones-effects-youthhtml). Some researchers argue that the mobile phones do more work than the Personal Computers (PCs) because they permit learners easy access to materials apart from giving them room to practice anytime anywhere (Reinders, 2010). Learners can store work and revise it on their phones. In addition, they can access online resources. However, learners do not automatically utilise cell phones. They should be taught to do so. It is incumbent upon a school to develop a culture of research via mobile phones.

Of importance is the versatility of mobile phones. They have facilities like calendars, calculators and reminders which promote learning (Brick, 2012). While a calendar allows learners to schedule homework and due dates, the reminder and alarm facility assists students to keep the study time and due dates. A calculator on a mobile phone reduces the items that a student carries to school (Brick, 2012). As learners schedule their work, they are trained to manage their own learning (Reinders, 2010).

The fact that a mobile phone facilitates communication needs not be overemphasised. Learners can be in touch with their parents and friends (Reinders, 2010; Brick, 2012). Fluid contact with friends and parents gives learners peace of mind (Reinders, 2010). Thus, mobile phones are social tools that prepare ground work for learning apart from 
propelling it.

Notably, students in rural day schools where resources are scarce can bridge the technological barrier by connecting to the global world through mobile phones (http://www.ehow.com/list_5955529_cell-phones-effectsyouthhtml). Schools can browse internet via mobile phones instead of waiting until PCs and electricity reach their stations. Comparing with a PC, a mobile phone proves to be cheaper and more convenient (Chinnery 2006; KakulsskiHulme \& Traxler, 2005).

The fact that mobile phones induce interest in learners cannot go without mention. Learners like the screen size limitations on the mobile phone (Chen, Hirsch \& Kinshak, 2008). Research report by Thornton and Houser (2003) revealed that Japanese learners preferred to use mobile phones for reading books and emailing. In a recently reported case, learners at St Antony's High School in Zaka, Zimbabwe smashed window panes in protest against banning of mobile phones at the school. Learners enjoy using mobile phones to the extent that they resist policies that hinder them. Mobile phones can be appropriated for use as learning utilities.

The appropriation of mobile phones as learning tools has challenges. A significant number of students do not have access to mobile phones (Reinders, 2010) with capacities that they need. Modern smart phones that are as good as computers are not ubiquitous. However, schools can sacrifice to buy a few smart mobile phones that students can share as is the case with PCs. Reinders (2010) notes that mobile phones can be counterproductive. For example, when mobile phones ring during a silent reading activity, they can disrupt it. This however, does not warrant total banning of mobile phones in schools as is the scenario with most schools in Zimbabwe. Instead, a policy can be engineered to regulate the use of mobile phones in schools to the benefit of the learner. Reinders (2010) suggests that a plan that focuses on a specific task should be devised to guide the use of mobile phones. With proper planning, mobile phones can be fruitful learning tools.

\section{Methodology}

\subsection{Research design}

This study is a comparative case study which is largely qualitative. In a case study, the researcher typically observes the characteristics of an individual unit. This could be a child, a clique, a school or a community (Cohen, Manion \& Morrison, 2011). The researchers found the case study suitable owing to its emphasis on describing in detail what goes on in a particular activity. In this case, the extent to which technology creates learning gaps that stratify learners was investigated. Focus was on an urban and rural day secondary school. This design enabled the researchers to make a thick description of the technology-rooted learning gaps that stratify learners (Creswell, 2008).

\subsection{Selection of participants}

The research was conducted in Masvingo, Zimbabwe at two day secondary schools, an urban and a rural. Urban and rural day secondary schools differ in that the latter lacks basic necessities such as books, laboratories, competent staff which the former enjoys. Purposive sampling technique was used (Chilisa \& Preece, 2005). Four (4) school administrators two from each school were chosen because the researchers judged them to be key sources of information pertaining to how technology stratifies learners. Four (4) teachers two from each secondary school were purposively selected because they teach computers. Forty (40) Form 4 learners, twenty from each school (ten males and ten females) were randomly selected for this study. The researchers deemed them to be key sources of information pertaining to the stratifying nature of technology.

\subsection{Research instruments}

For this study the researchers used interviews and an open-ended questionnaire to gather data. A semi-structured interview schedule was developed by researchers in order to gather qualitative data. The researchers conducted face-toface interviews with 4 school administrators. For 40 learners, a focus group interview was used. Three themes were covered namely: the learning gap that is created by technology, the extent to which technology- rooted learning gaps stratify learners and the ways in which the learning gaps can be minimised. Interviews permitted the researchers to collect both verbal and non-verbal data (Fielding, 2003). Furthermore the researchers could probe for clarity where ambiguity was a hindrance (Creswell, 2008). 
For 4 teachers an open-ended questionnaire was used. The researchers managed to capture the opinions of the participants at the same time guiding them to stick to questions pertinent to the research (Chilisa \& Preece, 2005). The open- ended questionnaire was preferred because data that were gathered could be easily summarized, compared and analyzed. The adherence to a prepared questionnaire and interview schedule enhanced content validity. That is, the ability of the aforementioned instruments to measure what they purport to measure (Haralambos \& Holborn, 2008).

\section{Findings and Discussion}

\subsection{Administrators' views on how the learning gaps created by technology stratify learners}

Four (4) (100\%) administrators who were interviewed confirmed that the student-computer ratio in a rural day secondary school stood at 3:1 as compared to 2:1 in an urban day secondary school. The aforementioned ratios indicate a shortage of computers in schools. Given that schools should be grounds where young people learn the capabilities of computers (Giddens, 2009); learners who share a computer may not get enough experience to enable them to learn. Thus where learner-computer ratio is big, technology-based learning gaps are bound to remain and culminate into career challenges.

When they were asked to indicate classes that did computers, 2 (50\%) administrators of an urban day secondary school reported that Form 1-3 learners were doing computers. Two (2) (50\%) administrators from rural day secondary schools indicated that some of the Form 1 and 2 learners were doing computers as an elective subject. That is, one of the practical subjects. Siddiqui (2004) found that the view of computers as one of the practical subjects relegates some learners to the periphery both at school and later in life. The world today is characterised by informatization. That is, it is driven by information technologies (Sibanda \& Maposa, 2010; Wang, 1994). These findings proved that some learners never experienced computers although they could be there. Such learners did not use computers to learn unless they had them at home. Both urban and rural day secondary schools had learners who lagged behind in terms of using ICT to learn. Thus technology stratified learners.

All the administrators for both rural and urban day secondary schools admitted that students had no access to internet at school and that it was in their plan to get connected to the world. Thus, the internet gap was eminent in secondary schools studied. This gap affected learners even if they miss technological touch at school, still find it awaiting them later in school and in life. The researcher's preliminary survey conducted at Great Zimbabwe University indicated that BA Part 1 students had problems in using the internet to access information especially for the first assignment. The technology gap created at secondary school level haunted the learners at higher education level. Eventually, it would disadvantage them when they join their career since business in the modern world is transacted via technology (Giddens, 2009, Smith, 1999).

To circumvent the technology-rooted learning gaps, all the administrators $4(100 \%)$ agreed that secondary schools should prioritise appropriation of technology for learning. Suther, Robertson and John (2009) posit that a computer that is appropriated into an instrument is an enhancer of learning. The administrators' view that technology should be the priority was supported by Zhao (2009) who avers that the trend in the world today is directed towards e-learning.

When they were asked to comment on the possibility of using smart cell phones for learning, all administrators and teachers for both rural and urban day secondary schools indicated that they banned the use of cell phones at school. One urban day secondary school head who was interviewed said,

In fact, cell phones impede learning. They disrupt learning by diverting students' attention to activities that do not promote learning. For instance, learners can listen to music during a lesson. Cell phones can ring and divert the attention of the whole class.

The observation by the head indicates that schools are far from using cell phones as learning tools. Research by Reinders (2010) confirms that mobile phones can be counterproductive if they are not well handled. However, this does not warrant complete ban of cell phone use in schools. Reinders (2010) also notes that cell phones should not be used anyhow; rather, specific guidelines should be devised to regulate the use of mobile phones as learning tools.

\subsection{Teachers' view of technology- based learning gaps in schools}

An open- ended questionnaire was administered to 4 computer teachers in order to check if they were preparing learners to use computers as learning tools. All the rural and urban day computer teachers agreed that they inculcated in learners basic typing, word processing, spread sheet and Power Point skills. No internet skills were imparted. Learners who claimed to be familiar with internet had accessed it elsewhere. Learners who were not exposed to the internet missed a plethora of free online educational resources which can be used to reinforce the concepts that are acquired in the 
classroom (Smith, 1999; Giddens, 2009). As long as learners lack basic computer skills, it becomes difficult to appropriate the tool in order to learn (Suther, Robertson \& John, 2009; Mariotti, 2002).

All the rural and urban day computer teachers revealed that learners in their schools did not use educational software packages even the free ones. More so, learners did not use soft copies of notes, past examination papers or mock tests. In light of this finding, learners in the schools studied rarely used computers to learn. If they did so, then they got the experience outside the school capacity. The convenience brought about by technology cannot be ignored. Dlamini (2012) acknowledges that soft copies are convenient for use by learners as they have the capacity to replace the burdensome paper. What it means is that learners who cling on to papers risk failing to match the technology-driven world we live in.

When they were asked how technology created learning gaps at school, 2 (50\%) urban day computer teachers revealed that students who had access to a computer at home were active in computer and other lessons. The students who had access to computers outperformed those who did not. Research revealed that many students still do not have computers at home (Giddens, 2009). Also the OECD 2003 report cited in Giddens (2009) found that regular use of computers led to better scores particularly in Mathematics. The issue is that the use of computers enhances learning. This result was confirmed by 2 (50\%) rural day teachers who indicated that learners who did computers though as one of the practical subjects, were more knowledgeable than those who had little or no access. Thus the absence of technology creates serious learning gaps which stratify learners. Watkin (2000) observed that technological learning gaps are an imminent danger that pervades learning and consequently one's career.

All the teachers agreed that secondary schools had to expose all learners to technology so that they fit into the computerised world (Dlamini, 2012; Zhao, 2009; Watkin, 2000). If the schools can execute this mandate then all students can board the technology plane which is roaming the world.

Two urban computer teachers indicated that they taught computers as a subject examined by HEXCO, an examining board housed under the Ministry of Higher and Tertiary Education. Examining of computers meant that learners would take them seriously. The rural day counterparts revealed that computers were taught as an appreciation course. The fact that the computers were not examinable meant that learners regarded them with contempt. This result indicates an urban-rural learning gap which stratifies learners. In light of this finding, schools should create high-tech learning environments (Smith, 1999) which permit learners to use technology to learn.

\subsection{Learners' view of technology-based learning gaps}

Out of the 20 rural day secondary school learners, only $1(5 \%)$ had access to a computer at home. It means that 19 (95\%) learners could catch a glimpse of a computer at school. In comparison, 10 (50\%) out of 20 urban day secondary school learners had access to a computer at home. In this respect, there is a huge technology-rooted learning gap between urban day and rural day secondary school learners. Studies have shown that the more one is exposed to computers, the more one is bound to learn (Giddens, 2009).

Out of the $10(50 \%)$ urban day learners who had no access to a computer at home, $5(50 \%)$ revealed that they sometimes accessed from the internet cafe. It follows that students in an urban day secondary school could access the internet through other means. Only $5(25 \%)$ urban day secondary school learners had no access to internet. In terms of the internet, rural day secondary school learners were miles behind when they were compared to their urban day counterparts who had access to internet from elsewhere. Research confirms that internet allows students to learn further on their own as they tweet, skype, use and re-use knowledge (Berns, 2010; Giddens, 2009; Watkins, 2000; Siddiqui, 2004).

Efforts to establish learners' access to smart mobile phones revealed that, 10 (50\%) urban day learners confirmed that they had access to smart cell phones at home as compared to $2(10 \%)$ rural day ones. It follows that rural day learners lag behind in terms of the benefits that mobile phones accrue to their users. Research proves that tremendous research can be done via mobile phones (http://www.ehow.com/list5955529cell-phones-effects-youthhtml). Apart from inducing interest, cell phones give learners the opportunity to practice school material anywhere anytime (Reinders, 2010; Chen, Hirsch \& Kinshak, 2008). More so, cell phones are not only cheap and convenient, but they are versatile (Brick, 2012; Chinnery, 2006). They entertain, inform, teach, motivate and remind learners through the various facilities installed in them. Although cell phones are prohibited in most schools in Zimbabwe, learners prefer to use them. Forty (40) (100\%) urban and rural day secondary school learners admitted that they preferred to use a smart cell phone to a computer. Schools should at this juncture consider using mobile phones as learning tools. Cell phones have the potential to reduce learning gaps that technology creates. 


\section{Conclusion and Recommendations}

The study revealed that technology-based learning gaps existed between learners who used technology and those who did not. ICT, especially the internet has become a new line of demarcation (Giddens, 2009) between the ICT rich and ICT poor schools. Students who were found to be backward in ICT were likely to face challenges in this technology-driven society. The use of ICT as a learning tool is still very low in both rural and urban day secondary schools. It emerged from the study that technology stratified learners from school to their respective careers. The study recommended that:

- Schools should reduce learning gaps by prioritising use of computers as learning and research tools.

- Computer education should be declared compulsory since it is indispensable in both the learning process and research.

- Mobile phones should be urgently appropriated as learning tools.

\section{References}

Berns, R.M. (2007). Child Family, School Community: Socialization and Support. Belmont:Thompson Wadsworth.

Brick, B. (2012). Benefits and Risks of a Cell Phone. [Online] Available: http://www.ehow.com/list6111707benefits-risks-cell-phone.html-ix22 (August 20, 2013).

Chen, N.S., Hsieh, S.W. \& Kinshuk, A. (2008). Effects of Short Term Memory and Content Representation Type on Mobile Language Learning. Language Learning and Technology, 12(3), 93-113.

Chilisia, B. \& Preece, L. (2005). Research Methods for Adult Educators in Africa. Capetown: UNESCO and Pearson Publishers.

Chinnery, G. (2006). Going to the Mall: Mobile Assisted Language Learning. Language Learning and Technology, 10(1), 9-16.

Cohen, L., Manion, L. \& Morrison, K. (2011). Research Methods in Education. London: Routledge.

Creswell, J.W. (2008). Research Design: Qualitative and Quantitative Approaches. London :Sage Publications.

Dlamini, B. (2012). Quality Educational Assessment in a Changing World: Trends and Challenges. Paper Presented at the 6 ${ }^{\text {th }}$ SAAEA Conference, 11-13 June, Esibayani Lodge, Matsapha, Swaziland.

Effects of Cell Phones on Youths. Available: http://www.ehow.com/list_5955529_cell-phones- effects-youthhtml (September 9, 2012).

Fielding, M. (2003). Effective Communication in Organization: Preparing Messages that Communicate. Cape Town: Juta and Company.

Giddens, A. (2009). Sociology. Cambridge: Polity Press.

Haralambos, M., Holborn, M. \& Heald, R. (2008). Sociology: Themes and Perspectives. London: Collins Educational.

Higher Education Examinations Council (1996). Regulations and Syllabus for the National Foundations Certificate in Computer Studies. Harare :MHTE.

Hudson, G. (2012). The Challenges of Introducing New Technologies in Assessment Globally. Paper Presented at the 6 ${ }^{\text {th }}$ SAAEA Conference, 11-13 June, Esibayani Lodge, Matsapha, Swaziland.

Kukulska-Hulme, A. \& Traxler, J. (2005). Mobile Learning: A Handbook For Educators and Trainers. London: Routledge.

Kitchen, S. Finch, S. \& Sinclair, R. (2007). Harnessing Technology Schools Survey 2007.

Coventry: Becta.

Mariotti, M.A. (2002). Influence of Technology Advances on Students Maths Learning in L1 English. In M. Bartolini, G. Jones, R. Bech \& D. Trosh (Eds.), Handbook of International Research in Mathematics Education, Mahwah (PP695-721). New Jersey: Lawrence Erlbaum Associates.

Nielsen, L. (2011). 10 Ways Technology Supports 21 $1^{\text {st }}$ CenturyLearners in Being Self Directed. Available: http://theinnovativeeducator.blogspot.com/ 2011/01/10-ways-technilogy- supports-21st.html (August 14, 2012).

Openheimer, T. (2003). The Flickering Mind: The False Promise of Technology in the Classroom and How learning Can be Saved. New York :Random House.

Perkins, D.N. (1985). The Fingertip Effect: How Information-Processing Technology Changes Thinking. Educational Researcher, 14(7), 11-17.

Reinders, H. (2010). Twenty Ideas for Using Mobile Phones in the Language Classroom. English Teaching Forum, 3, 2010.

Rotherham, J.A. \& Willingham, D. (2009). 21 $1^{\text {st }}$ Century Skills: The Challenges Ahead Teaching for $21^{\text {st }}$ Century. Educational Leadership, UNESCO, 67, 10.

Sibanda, F. \& Maposa, S. (2010). Beyond Y2K Compliance: The Impact of Multimedia Technology on Junior Secondary School Learners in Zimbabwe. International Journal of Educational Research and Technology, 1(2), 15-19.

Siddiqui, M.H. (2004). Technology in Higher Education. New Delhi: APH Publishing Corporation

Smith, H. (1999). Opportunities for Information and Communication Technology in the Primary School. London: Trentham Books.

Suther, I., Robertson, S. \& John, P. (2009). Improving Classroom Learning With ICT. London: Routledge Taylor and Francis Group.

Technology Zimbabwe (2012). 1000 Zimbabwe Schools to have e-Learning Facilities by December, ICT Minister. Available: http://www.techzim.html (August 14,2012).

Thornton, P. \& Houser, C. (2003). Using Mobile Web and Video Phones in English Language Teaching: Projects With Japanese Students. In B. Morrison, C. Green \& G.Motteram (Eds.) Directions in CALL: Experience, Experiments and Evaluation (PP207-224). Hong Kong: English Language Centre Hong Kong Polytechnic University.

Trouche, L. (2003). Form Artifact to Instrument: Mathematics Teaching Mediated by Symbolic Calculators. Interacting With Computers, 15(16): 783-800.

Turtle, S. \& Papert,I. (1990). Epistemological Pluralism: Styles and Voices Within the Computer Culture. Signs, 16(1), 345-377.

Verillion, P. \& Rabardel, P. 1(995). Cognition and Artefacts: A Contribution to the Study of Thought in Relation to Instrumental Activity. European Journal of Psychology of Education, 10, 77-101.

Wang, G. (1994). Treading Different Paths: Information in Asian Nations. New Jersey: Ablex.

Watkins, K. (2000). The Oxfam Education Report. London : Oxfam GB .

Wertsch, J. (1998). Mind as Action. New York: Oxford University Press.

Zhao, Y. (2009). Catching up or Leading the Way: American Education in the Age of Globalization. New York: Library of Congress Cataloguing in Publication Data. 